\title{
THEORETICAL ANALYSIS OF THE RELATIONSHIP BETWEEN THE ARCHITECTURAL ENVIRONMENT AND THE STRUCTURE OF PERSON'S SUBJECTIVE WELL-BEING
}

\author{
ТЕОРЕТИЧНИЙ АНАЛІЗ ВЗАЄМОЗВ'ЯЗКУ \\ МІЖ АРХІТЕКТУРНИМ СЕРЕДОВИЩЕМ ТА СТРУКТУРОЮ \\ СУБ'ЄКТИВНОГО БЛАГОПОЛУЧЧЯ ОСОБИСТОСТІ
}

UDC 159.922.26+316.613.4]:[72.01:111.852] DOI https://doi.org/10.32843/26635208.2020.14.21

\section{Lypetska A.S.}

Postgraduate Student

at the Department of Psychology

Ivan Franko National University of Lviv
The article contains a theoretical analysis of psychological literature regarding the position of an architectural environment in the structure of subjective well-being factors. The analysis of issues of subjective well-being phenomenon and its structure has been conducted. The existing approaches to the study of the concept of subjective well-being are considered and structured; the expediency of combining the basic principles of each of them for further research within this area is emphasized. It is stated that the concept of well-being in the context of hedonistic approach is viewed as experiencing certain contentment by an individual, and within the frameworks of eudemonistic approach - as a dimension of full-fledged living of an individual through self-realization. The phenomenon of architectural environment has been identified and substantiated in the context of psychological studies. It is emphasized that the fundamental function of the architectural environment underlies in structuring of its objects being diverse, but incompatible at the first sight, and transforming them in such a way that as a result of perception of this environment a person feels happy, satisfied and prosperous. The main goals that should serve as a basis of each architectural environment for its full functioning are considered. It is summarized that a harmoniously structured architectural environment, in terms of hedonistic approach, can be a place of contentment for its residents and guests. It is also noted that the architectural environment, in terms of eudemonistic approach, contributes to the development of the individual, their self-realization and achievement of goals. The fundamental position of the architectural environment in the life of each individual and humanity in general is emphasized. The prospect of further research is an empirical study of the interaction of the architectural environment and the structure of the subjective well-being of those who are in direct contact with it.

Key words: architectural environment, subjective well-being, psychological well-being, satisfaction, happiness, eudemonism, hedonism.

У статті представлено теоретичний аналіз психологічної літератури щодо місия архітектурного середовища в структурі чинників суб'єктивного благополуччя. Проаналізовано проблематику феномена суб'єктивного благополуччя та його структуру. Розглянуто та структуровано існуючі підходи до вивчення поняття суб'єктивного благополуччя та наголошено на доцільності поєднання основних засад кожного з ним для подальшого дослідження в рамках чієї проблематики. Зазначено, що поняття благополуччя в контексті гедоністичного підходу розглядається як переживання особистістю певного задоволення, а в рамках евдемоністичного підходу - як міра повноцінного існування особистості через самореалізацію. Вирізнено та обгрунтовано френомен архітектурного середовища в контексті психологічних досліджень. Підкреслено, що фрундаментальна фрункція архітектурного середовища полягає у структуруванні його різноманітних, на перший погляд, не сумісних один з одним, об'єктів та перетворюванні їх так, що в результаті сприймання цього середовища людина почувається щасливою, задоволеною, благополучною. Розглянуто головні цілі, які мають бути закладені в основу кожного архітектурного середовища для його повноцінного ффункціонування. Резюмовано, що гармонійно структуроване архітектурне середовище з погляду гедоністичного підходу може виступати місцем задоволення для його жителів та гостей. А також зазначено, що архітектурне середовище з позиції евдемоністичного підходу сприяє розвитку особистості, їі самореалізації та досягненню поставлених цілей. Підкреслено ффундаментальну позицію архітектурного середовища в житті кожноі людини окремо та людства загалом. Перспективою подальших розвідок $є$ емпіричне дослідження взаємозв'язку архітектурного середовища зі структурою суб'єктивного благополуччя осіб, які знаходяться в безпосередньому контакті з ним.

Ключові слова: архітектурне середовище, суб'єктивне благополуччя, психологічне благополуччя, задоволення, щастя, евдемонізм, гедонізм.
The global stressful situation has dramatically changed everyone's lives and opened the door to the popularity of the research into the phenomenon of person's subjective well-being. Scientists working in various fields arrange a comprehensive analysis of this phenomenon, complementing the structure of its exogenous and endogenous factors. In the modern scientific literature on the problem of person's subjective well-being, the role of exogenous factors, namely the architectural environment, is insufficiently disclosed. However, it evolves with humanity, is in direct contact with each individual and society as a whole. On the one hand, there is a common understanding that the architectural environment is an integral part of human life, and its impact is 
undeniable and significant. However, the question arises: can the architectural environment be included in the system of subjective well-being factors? Can the influence of the architectural environment determine the subjective well-being of its inhabitants?

At present, there are a number of scientists who dedicate their research to substantiating the multifaceted phenomenon of subjective well-being and identifying its exogenous and endogenous factors: E. Diener, N. Bradburn, M. Seligman, P. Costa, J. Ware, R. Vallerand, N. Hafarova, A. Adler, P. Fesenko, H. Puchkova, L. Kulykov, T. Campbell, R. Ryan, E. Deci, C. Ryff, M. Jahoda, D. Leontiev, R., Shamionov, I. Dhidarian, O. Shyriaieva, M. Baturina, etc. Over time, the list of subjective well-being factors is getting longer as each researcher is trying to improve the structure of this concept. To fully understand it, one should bear in mind that as the phenomenon itself changes, so do its components. Financial and economic factors of subjective well-being are described in the works of T. Campbell, E. Diener, A. Baranov, V. Khashchenko, O. Uhlanov, D. Groenland, etc. Indicators of physical health in the structure of well-being were analyzed by $\mathrm{J}$. Ware, R. M. Ryan, M. Argyle, L. Kulykov, P. Fesenko, etc. The influence of spiritual development on human well-being was studied by D. Brothers, C. Dalbert, M. J. Lerner, J. Bennett, D. Leontiev. Personality traits in the context of the issue of subjective well-being were analyzed by M. Baturin, S. Bashkatov, N. Gafarova, and cultural features were analyzed by E. Diener, M. Diener, life prospects of the individual were analyzed by $R$. Ryan, J. G. La Guardia. The dominance of certain emotions also has an impact on human well-being, as stated by E. Diener, R. E. Lucas in their studies. Socio-demographic factors should also be noted (N. Bradburn, J. R. Hackman, P. Warr, D. Raphael, A. Adler, S. Druzhylov, T. Danylchenko), as should existential (N. V. Hrishyna, M. Zanadvorov, V. Frankl) and no less important natural factors (N. Hrankina-Sazonova, I. Kriazh, H. Frumkin, K. Walsh; A. Howell). The architectural environment as a subjective well-being factor is an undeveloped issue, although there are studies of the peculiarities of interaction between humans and architectural environment, which are substantiated within the field of environmental psychology. The relationship between architecture and the emotional world of a human being has repeatedly been pointed out in the study of architectural semiotics by A. Barabanov, Yu. Yankovska, F. Chortiv, M. Puchkov, A. Serhieiev; in the field of architectural theory C.-N. Ledoux, J. Simonds, R. Arnheim, I. Strautmanis, H. Zabelshanskii, H. Mynervyn, H. Rappoport, H. Somov, A. Ikonnykov, M. Smolina, A. Bunin, V. Iovlev, T. Korepyna, M. Lymonad, A. Tsyhanov, etc. In the field of psychological and psychophysiological research, this issue was described in the works of R. L. Gregory, I. Rock, J. Gibson, L. A. Kytaiev-Smyk, M. Chernoushek, V. A. Filin, etc. Theoretical and practical basis of environmental psychology is composed of the studies by the below scientists: K. Lynch, E. Hall, I. Altman, J. Gibson, R. Sommer, D. Stocols, etc. Therefore, the need to study the architectural environment as an exogenous factor of subjective well-being in today's context acquires not only theoretical but also practical significance for the harmonious development of both the individual and humanity as a whole.

That is why the objective of the article is to theoretically analyze the significance of human interaction with the architectural environment through the prism of its subjective well-being.

Analyzing the appearance of architectural environment alone, each of us can trace how the life and history of our ancestors changed, just as our descendants will be able to feel the spirit of our era. The architectural environment is a significant part of the life of both the individual and humanity as a whole, it can concentrate in itself the features of each nation, but unfortunately it is sometimes underestimated by us. The environment surrounding humans changes according to the evolutionary processes of mankind, ancient Greek architecture is significantly different from modern architecture, but it was back in the ancient times that the basis for shaping the environment so that it has a beneficial effect on inhabitants were formed. Some authors define the architectural environment as a set and integrity of internal and external spaces, forms and structures that ensure the full-fledged human life activities on the basis of the architectural, city-planning and design laws and rules [7]. This definition shows that the architectural environment is a certain structured system of objects that surround us when we go outside, namely: architectural structures (buildings, monuments, etc.), squares, parks, roads, etc. According to V. Shylin, at the heart of every architectural environment there are the below goals:

- Functional arrangement of life processes in planning decisions;

- Rationalization of activity, structural and logical arrangement of architectural and spatial environmental information;

- Arrangement and management of life activities using functional and planning means;

- Expression of cultural and historical ideals;

- Conveying architectural-spatial, functionalplanning meanings through architectural-spatial means;

- Figurative expression and aesthetic harmonization of the living environment; emotional and artistic expressiveness and communicability of the architectural and spatial environment; 

ment;

- Creation of ecologically healthy living environ-

- Ensuring the safety of life" [8, p. 9].

Analyzing the above from a psychological point of view, we can conclude that the architectural environment is designed to structure its facilities and transform them in such a way that in the end a person develops a positive emotional response, happiness, satisfaction, etc. Ch. Montgomery, in his work on the analysis of the city's environment, argues that the environment should give its residents a sense of joy, minimize life difficulties, ensure physical health, freedom, a sense of control and comfort, and directly create conditions for a sense of meaning of life and help develop resilience in the face of economic or environmental shocks [4]. We can be subjectively prosperous by harmoniously arranging the space of our lives, taking into account all our needs. Person's attitude to the environment, in some respects, has always been consumerist in nature. Assessing the essence of each person's life, we can conclude that each of us strives to be happy and this was argued in the studies by scientists from different fields and different eras. "There is nothing sweeter for a person and nothing more needful than happiness..." [6, p. 76]. These words of $\mathrm{H}$. Skovoroda best describe the importance of being happy for each of us. Today, the issue of making a person happy is dealt with by a fairly new area of psychology "positive psychology" - where the basic concept is the person's well-being. Over the past few decades, the relevance of the study of the phenomenon of person's well-being has increased, but there is no unambiguous definition thereof. "It is easier to imagine well-being as a concept than to try to give it a definition" [15, p.1]. The concept of well-being is often equated with the concept of happiness, satisfaction and other concepts, but it is not the same thing. The substantiation of the concept of well-being dates back to the philosophical studies and it is in these works that it appears as happiness and life satisfaction. In the context of psychological sciences in the late 20th century, scientific research into the concept of "well-being" was structured into the below main approaches: hedonistic and eudemonistic. Each of these approaches originated dates back to the antiquity; their interpretations have certain similarities and differences. The hedonistic approach interprets the concept of "well-being" as pleasure intertwined with the constant internal struggle between what is deemed to be good and bad. At the heart of hedonism, pleasure is interpreted as the highest good and the meaning of life [2]. N. Bradburn, who developed his works in the context of the hedonistic approach, interpreted this concept as a kind of balance that can be achieved through the constant interaction between positive and negative affect, which results in satisfaction or dissatisfaction [9]. $\mathrm{He}$ also introduces the concept of psychological well-being. His follower, E. Diener, as a result of his scientific activity, introduces the term "subjective well-being" as a three-component structure, with the below components: satisfaction, pleasant emotions and unpleasant emotions. It should be noted that subjective well-being is a multifaceted concept that includes both cognitive and emotional assessment of various aspects of human life [11]. According to this approach, person's subjective well-being can be compared with the feeling of happiness [10]. Therefore, the intensity of person's positive emotions forms their level of subjective well-being, so we can assume that after immersing a person in a harmoniously structured environment, the intensity of pleasant emotions will increase and this will directly affect person's well-being. Consideration of the impact of architectural environment on the person's subjective well-being through the prism of a hedonistic approach reveals the level of emotional impact of this environment on its inhabitants and the ability to filter out its positive and negative aspects. In other words, the architectural environment that accompanies a person throughout his/her life, can be a place of pleasure. For example, if the architectural environment evokes positive emotions, good memories are associated with it, if it evokes pleasant smells, if it is safe and comfortable, then a person who is in interaction with this environment has positive emotions, which in turn affects his/her well-being.

Within the humanistic psychology, the concept of well-being is studied through the prism of the eudemonistic approach, based on the term of psychological well-being and aspects of positive human functioning. The main idea behind this approach is the idea of the meaning of life and self-realization of the individual, with well-being being a certain measure of human existence. The below researchers adhered to the eudemonistic approach in their studies: Aristotle, J. Bugental, A. Maslow, C. Rogers, E. Fromm, G. Allport. C. Riff, C. Jung, E. Erickson, etc. In his works, E. Deci noted that well-being is not a certain end state, it is a process of fulfilling one's potential [10]. Studying the phenomenon of well-being, C. Riff pointed out that the main thing is the feeling of successful fulfillment of one's own potential rather than satisfaction [4]. M. Seligman noted that a person with eudemonistic lifestyle, i.e. a person who is developing, fulfilling own potential, experiences joy for a longer period of time [14]. L. Kulykov identified a number of components of personal well-being in his works: social - satisfaction with position in society; spiritual - involvement in a particular spiritual culture; financial - the presence of a financial "cushion"; physical - physical comfort, good physical health; psychological a sense of inner balance [3]. H. Puchkova also 
analyzed the structure of subjective well-being, she identified three fundamental components: cognitive, which includes ideas about well-being and the future; emotional and evaluative component - optimism, positive attitude to others and to oneself, independence, authenticity; motivational and behavioral component - control over circumstances and life goals [5]. As a result of a scientific experiment, C. Riff formed a unique structure of well-being, which includes the following components: self-acceptance, i.e. awareness and acceptance of diversity by a person; positive relationships with others, namely the ability to empathize, establish and maintain contacts with others, as well as to be open and flexible in interaction; autonomy - the ability of a person to be independent in their thoughts, prejudices and actions from the society; environmental management - creating convenient conditions to meet their own needs and goals; goal - a sense of understanding own present, past and future; personal growth throughout person's life [12]. She also developed a unique method of identifying the components of the structure of psychological well-being, which allows us to analyze and justify its various aspects [13]. Based on the views of the eudemonistic approach researchers as to understanding the structure of the phenomenon of subjective well-being, we consider the architectural environment as a place of realization of the main components of the structure of this phenomenon. Thus, the life history of mankind has always developed within a certain architectural environment, in other words, this environment is the scene of our lives. Depending on the level of arrangement of various objects in this environment, a person will overcome everyday life difficulties in a different way, and will or will not feel inner freedom to achieve new goals and conquer new peaks. And the symbolic language of architecture is able to give a feeling of self-confidence in the future. Therefore, studying the influence of architectural environment on the subjective well-being, it is advisable to consider the phenomenon of "subjective well-being", given the features of hedonistic and eudemonistic approaches, as an "integral dynamic formation, which does not provide for the simultaneity of positive vectors in all areas of activity, is characterized by diachrony of different components, but is formed due to a certain critical accumulation and reflection of experience" [1, p. 12]. The architectural environment is a constant companion of our lives; it shapes us as individuals and reflects the life of each individual and humanity as a whole.

Conclusions drawn from the study: A number of attempts have been made in the field of psychological sciences to substantiate the concept of subjective well-being and to determine its structure of factors. Although the issue of "subjective well-being" is a very popular topic in the scien- tific community in various fields, but a single terminology has not been defined, therefore in most studies it is considered as a certain combination of basic ideas and views. Scientific works on this issue can be divided into two main approaches: hedonistic, in which the concept of "well-being" is seen as pleasure, and eudemonistic approach, which is based on the understanding of "well-being" as a measure of the person's full and fulfilling existence. The basic principles of hedonism are manifested in each of us through the striving for the best, most attractive and most comfortable architectural environment, because it is only the perfect that can ensure our satisfaction. At the same time, we exhibit the principles of eudemonism through the desire to realize ourselves and our inner potential, through the achievement of our desires and goals, using the latest benefits of the surrounding architectural environment and we are enjoying this process. The structure of architectural environment can contribute to human development, while humans can change the environment depending on their own needs. To create and arrange harmonious architectural environment, all possible components of its positive and negative impact should be identified.

To sum up, it should be noted that the fundamental analysis of the impact of architectural environment on the structure of subjectivewell-being is extremely important in the context of modern globalization and the crisis of humanity, so the prospect of further work is an empirical study of the relationship between the architectural environment and the structure of person's subjective well-being that is in direct contact with that environment.

\section{REFERENCES:}

1. Абрамюк О., Липецька А. Концептуальна структура френомену суб'єктивне благополуччя та особливості його вимірювання. Психологія: реальність $i$ перспективи. 2018. Вип. 11. С. 10-17.

2. Казанцева Р.И. О психологии простым языком. Что такое гедонизм: понятие и суть гедонистического образа жизни. 2007. 280 с.

3. Куликов Л. В. Психогигиена личности. Вопросы психологической устойчивости и психопрофілактики : учебное пособие. Санкт-Петербург : Питер, 2004. 464 c.

4. Монтгомери Ч. Счастливый город. Как городское планирование меняет нашу жизнь / пер. с англ. Ю.М. Константиновна. Москва : Манн, Иванов и Фебер, 2019. 368 с

5. Пучкова Г.В. Субъективное благополучие как фрактор самоактуализации личности : дис. ... кандидата психологических наук : 19.00.01. Хабаровск, 2003. 163 c.

6. Сковорода Г.С. Розмова про істинне щастя / пер. укр. мовою; прим. В.О. Шевчука. Харків : Прапор, 2002. 280 с.

7. Основи дизайну архітектурного середовища : підручник / В.О. Тімохін та ін. Київ: КНУБА, 2010. 400 с. 
8. Шилин В.В. Архитектура и психология : краткий конспект лекций. Нижний Новгород : Нижегород. гос. архит.-строит. ун-т, 2011. 66 с.

9. Bradburn Norman M. Asking Questions: The Definitive Guide to Questionnaire Design For Market Research, Political Polls, and Social and Health Questionnaires, Revised Edition. San Francisco: Jossey-Bass A Wiley Imprint, 2004. 429 p.

10. Deci E.L. \& Ryan R.M. (2008). Self-determination theory: A macrotheory of human motivation, development, and health. Canadian Psychology/Psychologie canadienne, 49(3), 2008. P. 182-185. URL : https://doi.org/10.1037/a0012801.

11. Diener E. The science of well-being: the collected works. Series: Social Indicators Research Series. 2009. Vol. 37. 274 p.
12. Ryff C. Know Thyself and Become what You Are: A Eudaimonic Approach to Psychological Well-Being Carol D. Ryff, Burton H. Singer. Journal of Happiness. 2008. № 9. P. 13-39.

13. Ryff C. The Structure of Psychological Well-Being Revisited. Journal of Personality and Social Psychology. 1995. Vol. 69. № 4. P. 719-727.

14. Seligman M.E.P. Positive psychology, positive prevention, and positive therapy. In C. R. Snyder \& S. J. Lopez. Handbook of positive psychology. Oxford University Press, 2002. P. 3-9.

15. Wollny I., Apps. J., Henricson C. Family wellbeing. Can government measure family wellbeing. A literature revies. London: Family and Parenting Institute. 2010. 92 p. 